\title{
Assessment of the Kraków inhabitants' health risk caused by the exposure to inhalation of outdoor air contaminants
}

\author{
Agnieszka Gruszecka-Kosowska ${ }^{1}$
}

Published online: 9 December 2016

(C) The Author(s) 2016. This article is published with open access at Springerlink.com

\begin{abstract}
Health risk associated with the exposure to the polluted atmospheric air inhalation was estimated for the residents of Kraków, Poland. The air pollution concentration data were obtained from the air-quality monitoring system of the city in 2007-2016. The carcinogenic risk of the studied subpopulations was not acceptable under the formula of $\mathrm{C}_{6} \mathrm{H}_{6}>\mathrm{BaP}>\mathrm{As}(\mathrm{PM} 10)>\mathrm{Cd}(\mathrm{PM} 10)>$ $\mathrm{Pb}(\mathrm{PM} 10)>\mathrm{Ni}(\mathrm{PM} 10)$. The total carcinogenic risk $(\mathrm{Rt})$ amounted to 3.04E-04 for children, 2.22E-04 for infants, $1.45 \mathrm{E}-04$ for women, and 1.22E-04 for men. The same risk was calculated for the top three locations of the monitoring stations in this respect, within the city of Kraków: Kurdwanów Housing Estate, Nowa Huta district, and Krasińskiego Av. Non-carcinogenic risk in the case of all six monitoring stations and in respect of all the studied subpopulations, resulting from the exposure to PM10 and for $\mathrm{NO}_{2}$ for all stations in case of children and infants, as well as, for adults at Krasińskiego Av. and Dietla Str. stations was rated medium. For $\mathrm{C}_{6} \mathrm{H}_{6}$ in the case of adults, children, and infants the risk was rated low. The total risk (HI) of non-carcinogenic pollution was rated medium and ranged as follows: 6.53 for children, 4.70 for infants, 3.19 for women, and 2.67 for men. That type of risk was decreasing at the station locations as follows: Krasińskiego Av. $>$ Dietla Str. $>$ Nowa Huta district $>$ Kurdwanów Housing Estate $>$ Złoty Róg Str. $>$ Piastów Housing Estate.
\end{abstract}

Agnieszka Gruszecka-Kosowska

agnieszka.gruszecka@agh.edu.pl

1 Department of Environmental Protection, Faculty of Geology, Geophysics, and Environmental Protection, AGH University of Science and Technology, Mickiewicza Av. 30, 30-059 Kraków, Poland
Keywords Air pollution · Human health · Risk assessment · Kraków · Inhalation · Air monitoring

\section{Introduction}

In several recent years, air quality became the most important issue for the environmental protection agencies and organisations all over the world ( $\mathrm{Lu}$ et al. 2008). Significantly exceeded air quality standards are common for cities in China: i.e. Beijing, Shanghai, Baoding, Xingtai, Shijiazhuang (Shao et al. 2006; Jiming et al. 2007; Kan et al. 2012; China names ten most polluted cities 2015; Zhou et al. 2015), India: i.e. Delhi, Raipur, Kanpur, Agra (Beig et al. 2013; Pant et al. 2016), Saudi Arabia: i.e. Riyadh, Dammam (Munir et al. 2016), as well as in Europe: Bulgaria (Dimitrovgad, Dolny Voden, Montana), Czech Republic (Havirov, Cesky Tesin, Orlova) or even Italy (Soresina, Settimo Torinese, Brescia) (WHO 2016). The improvement of the air quality is the huge challenge not only for Kraków, but also for many other Polish cities (i.e. Żywiec, Pszczyna, Rybnik, Sucha Beskidzka). The most recent WHO report specified that as many as 33 cities of the 50 most polluted ones in EU were located in Poland, and Kraków occupied position no. 11 on the list (WHO 2016). Owing to the growing ecological awareness among the residents, who do not agree to live in such arduous conditions affecting their health and wellbeing, the air quality issue has became widely publicised. According to EEA statistics, air pollution in Poland causes around 44,600 premature deaths a year attributable to PM2.5; 1100 to $\mathrm{O}_{3}$; and 1600 to $\mathrm{NO}_{2}$ (EEA 2015).

Air pollutants bring negative health effects, mainly in the respiratory tract and cardiovascular systems (Peters et al. 2001; Brunekreef and Holgate 2002; Pope et al. 2002; Brook et al. 2004; Haining et al. 2007), including increased death 
rates in populations (Samet et al. 2000; Polichetti et al. 2009; Lippmann et al. 2013; Wang et al. 2014). It is also suggested that birth weight is associated with air pollution during pregnancy (Ribeiro et al. 2014). Considerable attention is paid to suspended dust pollution, not only due to its respirability, but also owing to the possibility of causing additional negative health consequences relating to the chemical and biological composition of dust (Gemenetzis et al. 2006; Lu et al. 2008; Oeder et al. 2012). Trace elements (mainly $\mathrm{As}, \mathrm{Cd}, \mathrm{Pb}$, and $\mathrm{Hg}$ ), adsorbed at large specific surface areas of dust particles, are responsible for inflammations, lung and heart diseases, as well as DNA damage (Taner et al. 2013; Satsangi et al. 2014; Taiwo et al. 2016). Such ailments are observed especially in Kraków.

Lowering the air pollution to permissible levels, in case of cities like Kraków, it will take at least few, more likely over a dozen years. The risk assessment will give inhabitants the information, which activities and when should be avoided for their health, while no other actions are possible at present (except the change of the place of living). Still, health risk analyses for inhabitants owing to exposure of contaminants inhalation are not common. If any, such analyses are performed in developed countries i.e. Japan (Iwai et al. 2005), France (Morelli et al. 2016), Spain (López et al. 2017), United States (Wilson et al. 2015) or Switzerland (Vienneau et al. 2015), which inhabitants are aware of risks from environmental health hazards.

The author's research indicates that no health risk assessments have been conducted in respect of the Kraków residents, in connection with polluted air breathing. Trojanowska and Świetlik (2012) carried out tests relating to environmental exposure to heavy metals and the cancer risk associated with inhalation of benzo[a]pyrene (2013) in the selected Polish cities (not Kraków). Besides, air pollution studies were also conducted in Kraków, e.g. by Samek (2009), Worobiec et al. (2010), Styszko et al. (2015), Wilczyńska-Michalik et al. (2015), Wilczyńska-Michalik and Michalik (2015) (not the risk assessment). Taking above under consideration, on the basis of the available data for Kraków the preliminary risk assessment was calculated to indentify the risk value, define missing information for the future complete risk analyse. Author believes that detailed health risk assessment owing to polluted air inhalation with society involvement can affect the Kraków's descendants to improve the air quality as soon as possible.

Air pollution has been a considerable problem in the city of Kraków for several dozens of years. Between the 1950s and the 1980s, the rates of gaseous and dust air pollution constantly increased, which was associated with the development of industry and the operation of combined heat and power plants and steelworks in Kraków. However, we have to have in mind that since then also increasing number of inhabitants with coal fired heating installations in their houses contributed to a gradual deterioration of the air quality in Kraków. Decentralization of the government and privatization processes starting in the $1990 \mathrm{~s}$, decrease of industrial production, together with the implementation of new low-emission control technologies, led to continuous decline of pollution rates (Oudinet et al. 2006). However, the concentrations of PM, NOx, $\mathrm{O}_{3}$ in Kraków, caused nowadays by power plants, low emissions (Jędrychowski et al. 2005, 2013), and traffic (Oettl et al. 2003; Dziugieł et al. 2012; Adamiec et al. 2016; Oleniacz et al. 2016a), remain still much too high. Moreover the unfavorable meteorological conditions i.e. the low wind speed and low mixing-layer height worsen the air quality in Kraków, especially in winter months (Oleniacz et al. 2016b). Several research projects confirmed high cardiovascular and respiratory system disease incidence, mainly of asthma and allergies (Indulski and Rolecki 1995; Jędrychowski 2000; Jędrychowski et al. 1997, 2003, 2015), and increased mortality rates (Katsouyanni et al. 1996, 1997, 2001; Krzyżanowski and Wojtyniak 1991; Wiwanitkit 2008).

The air quality testing has been conducted in Kraków under the framework of the State Environmental Monitoring System by the Regional Environmental Protection Inspectorate (WIOŚ). In Poland air-quality test results are referred to the allowed pollution norms, determined on the basis of the respective Polish and EU legal regulations. The WIOŚ system is distributed over 6 air-quality monitoring stations under both automatic and manual regimes. Until December 2015, three monitoring stations were operating (Fig. 1): Krasińskiego Av. (Point D in Fig. 1), Kurdwanów Housing Estate (Point F) and Nowa Huta district (Point C). In December 2015, three more stations were established at the following locations: Dietla Street (Point E), Złoty Róg Str. (Point A), and Piastów Housing Estate (point B). It is planned that from 1st January 2017 two more air-quality stations will operate. Presently, the following types of pollution are measured at six air-quality monitoring stations: Krasińskiego Av. (station code: PL0012A): benzene $\left(\mathrm{C}_{6} \mathrm{H}_{6}\right)$, carbon oxide $(\mathrm{CO})$, nitrogen oxide $(\mathrm{NO})$, nitrogen dioxide $\left(\mathrm{NO}_{2}\right)$, nitrogen oxides (NOx), and particulate matter PM10 and PM2.5; Piastów Housing Estate (MAL031): PM10; Złoty Róg Str. (MAL032): PM10; Kurdwanów Housing Estate (PL0501A): $\mathrm{NO}, \mathrm{NO}_{2}, \mathrm{NOx}$, ozone $\left(\mathrm{O}_{3}\right)$, PM10, sulphur dioxide $\left(\mathrm{SO}_{2}\right), \mathrm{PM} 2.5$, arsenic in particulate matter As(PM10), benz[a]anthracene (BaA), benzo[a]pyrene $(\mathrm{BaP})$, benzo[b]fluoranthene $(\mathrm{BbF})$, benzo[j]fluoranthene $(\mathrm{BjF})$, benzo[k]fluoranthene $(\mathrm{BkF})$, $\mathrm{C}_{6} \mathrm{H}_{6}$, lead ( $\left.\mathrm{Pb}(\mathrm{PM} 10)\right)$, cadmium (Cd(PM10)), dibenz [a,h]anthracene (DBahA), and nickel (Ni(PM10)); Dietla Str. (MAL028): NO, $\mathrm{NO}_{2}$, NOx, and PM10; and Nowa Huta district (PL0039A): $\mathrm{C}_{6} \mathrm{H}_{6}, \mathrm{CO}, \mathrm{NO}, \mathrm{NO}_{2}, \mathrm{NOx}, \mathrm{PM} 10, \mathrm{SO}_{2}$, PM2.5, As(PM10), BaP, Cd(PM10), Ni(PM10), and $\mathrm{Pb}$ (PM10) (WIOŚ 2016). 


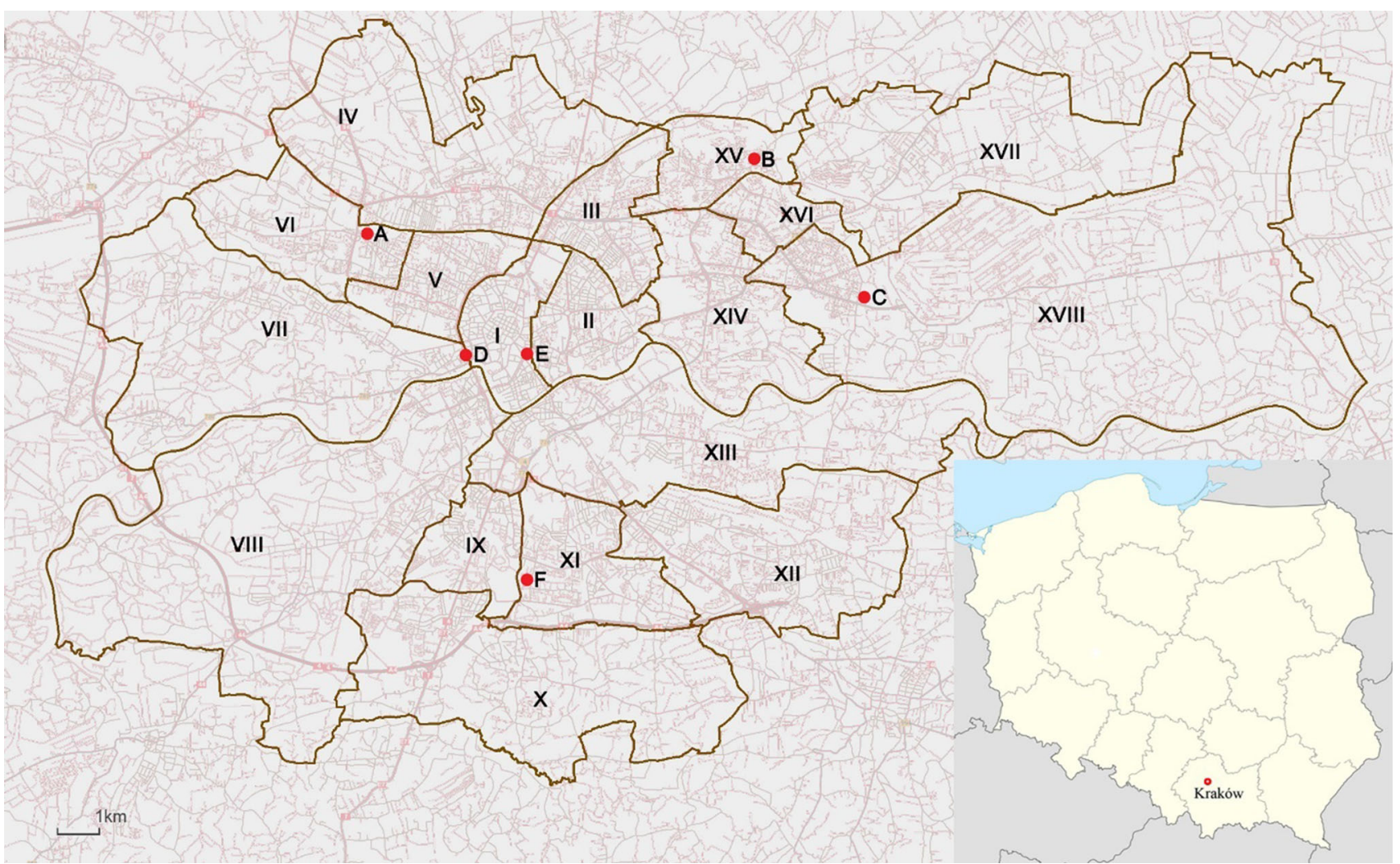

Fig. 1 Location of the air-quality monitoring stations in Kraków, I$X V I I I$ Kraków district numbers, $A-F$ air-quality monitoring stations of the Regional Environmental Protection Inspectorate in Kraków

While, we do not always obtain answers to the frequently asked question what is the level of health risk associated with breathing polluted air when analysing the test results, the purpose of the present course of study was to determine potential health risk to the residents of Kraków, resulting from exposure to atmospheric air pollution inhalation. Risk analysis was conducted on the basis of the pollution concentration in the atmospheric air from January 2007 to May 2016, performed by the Regional Environmental Protection Inspectorate in Kraków as part of the State Environmental Monitoring System.

\section{Materials and methods}

The health risk relating to inhalation exposure in Kraków, described in this paper, constitutes a preliminary study due to the availability of a high proportion of estimated data which increase uncertainty in research. However, in the author's opinion, such studies are still extremely important which will be demonstrated below. Our risk analysis refers to mean values of atmospheric air pollution rates, obtained at the airquality monitoring stations in Kraków from January 2007 to May 2016. Specific results were made available on-line at WIOŚ website: http://monitoring.krakow.pios.gov.pl/.
(WIOŚ), A Złoty Róg Str., $B$ Piastów Housing Estate, $C$ Nowa Huta district, $D$ Krasińskiego Av., $E$ Dietla Str., $F$ Kurdwanów Housing Estate

\subsection{Pollutant concentrations}

The pollutant concentrations in the atmospheric air were obtained from the online database of the Regional Environmental Protection Inspectorate in Kraków. The measurement data were used to calculate the arithmetic mean and the 95th percentile of the pollution value of 2007-2016 (measurement data were analysed until May 2016), separately for each monitoring station and for the six monitoring stations in Kraków together of (Table 1). The present risk analysis does not take into account the pollution rates (measured by the state monitoring system), for which SF or RfD values (see Sect. 2.2 below) have not been determined. The concentration values of the selected pollutants calculated in that way were used to estimate the risk values.

\subsection{Health risk assessment}

The health risk evaluation for the inhalation pathway exposure to pollution was determined by the US EPA (2007) methodology. Our analysis took into account the pollution rates covered by the Regional Monitoring System and included in the toxicological databases, specifying the Slope Factor (SF) values for carcinogenic pollutants and 


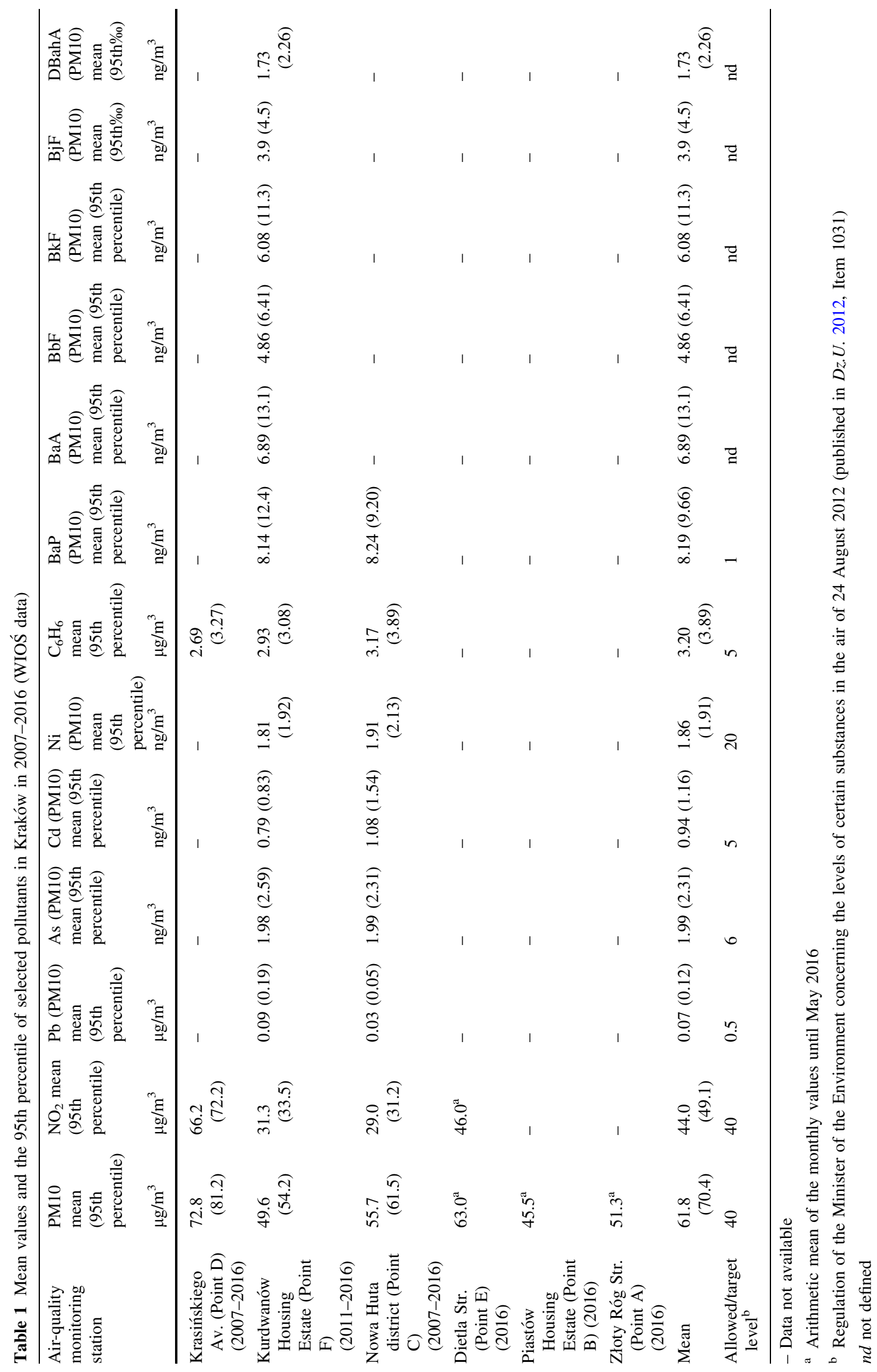


Reference Dose (RfD) values for non-carcinogenic ones. The values were treated as either carcinogenic or noncarcinogenic, in respect of $\mathrm{As}, \mathrm{Pb}, \mathrm{Cd}, \mathrm{Ni}$, and $\mathrm{C}_{6} \mathrm{H}_{6}$. Both types of risk rates were calculated here. Non-carcinogenic substance risk rates were calculated for $\mathrm{PM} 10$ and $\mathrm{NO}_{2}$ and carcinogenic ones for $\mathrm{BaP}, \mathrm{BaA}, \mathrm{BbF}, \mathrm{BkF}, \mathrm{BjF}$, and DBahA. However, no SF or RfD toxicological parameters were found in the toxicological databases for the remaining types of pollution tested by the Regional Monitoring System in Kraków.

\subsubsection{Estimated daily intake}

The estimated daily intake was determined according to four subpopulations identified, i.e. adult men and adult women ( $>7$ years old), children (1-7), and infants (0-1). The following formula (1) (ATSDR 2005) was applied to calculate daily intake rates of each subpopulation:

$\mathrm{EDI}=(\mathrm{C} \times \mathrm{IR} \times \mathrm{AF} \times \mathrm{F} \times \mathrm{ED}) /(\mathrm{BW} \times \mathrm{AT})$

where EDI Estimated daily intake ( $\mathrm{mg} / \mathrm{kg}$ body weight per day), C Contaminant concentration $\left(\mathrm{mg} / \mathrm{m}^{3}\right)$, IR Intake rate $\left(\mathrm{m}^{3} /\right.$ day), AF Bioavailability factor (unitless), F Frequency of exposure (days/year), ED Exposure duration (years), BW Body weight (kg), AT Averaging time $(\mathrm{ED} \times 365$ days/year) (days).

The estimated daily intake was calculated with the use of the following numerical values: $\mathrm{IR}=20 \mathrm{~m}^{3} /$ day for an adult, $10 \mathrm{~m}^{3} /$ day for a child, and $4.5 \mathrm{~m}^{3} /$ day for an infant; $\mathrm{AF}=1$, with the assumption that $100 \%$ of inhaled pollution is bioavailable, $\mathrm{F}=365$ days/year; $\mathrm{ED}=30$ years for an adult, $\mathrm{ED}=6$ for a child, and $\mathrm{ED}=1$ year for an infant; BW $=65.4 \mathrm{~kg}$ for a woman, $78.1 \mathrm{~kg}$ for a man, $16 \mathrm{~kg}$ for a child, and $10 \mathrm{~kg}$ for an infant. The parameters concerning the body weight were taken from Trojanowska and Świetlik (2012). All other parameters used in our calculations were specified by the US EPA (2013).

\subsubsection{Carcinogenic risk of outdoor air inhalation}

The following formula (2) (US EPA 2007) was applied to calculate the risk values of the carcinogenic substances:

$\mathrm{R}=\mathrm{EDI} \times \mathrm{SF}$

where R Cancer risk (unitless), EDI Estimated daily intake (mg/kg body weight per day), SF Inhalation Slope Factor $\left[(\mathrm{mg} / \mathrm{kg} \text { body weight per day })^{-1}\right]$.

The Slope Factor (SF) values, used in our calculations, were as follows: [(mg/kg body weight per day $)^{-1}$ ] (CalEPA 2016): $\mathrm{Pb}=4.20 \mathrm{E}-02 ; \mathrm{As}=1.2 \mathrm{E}+01 ; \mathrm{Cd}=$ $1.5 \mathrm{E}+01 ; \quad \mathrm{Ni}=9.1 \mathrm{E}-01 ; \quad \mathrm{BaP}=3.9 \mathrm{E}+00 ; \quad \mathrm{BaA}=$
$3.9 \mathrm{E}-01 ; \quad \mathrm{BbF}=3.9 \mathrm{E}-01 ; \quad \mathrm{BkF}=3.9 \mathrm{E}-01 ; \quad \mathrm{BjF}=$ $3.9 \mathrm{E}-01 ; \mathrm{DBahA}=4.1 \mathrm{E}+00 ; \mathrm{C}_{6} \mathrm{H}_{6}=1.00 \mathrm{E}-01$.

\subsubsection{Non-carcinogenic risk of outdoor air inhalation}

The following formula (3) (US EPA 2007) was applied to calculate the risk values of the non-carcinogenic substances:

$\mathrm{HQ}=\mathrm{EDI} / \mathrm{RfD}$

where HQ hazard quotient (unitless), EDI Estimated daily intake (mg/kg body weight per day), RfD Reference Dose ( $\mathrm{mg} / \mathrm{kg}$ body weight per day).

The Reference Dose values (RfD) were as follows ( $\mathrm{mg} / \mathrm{kg}$ body weight per day): PM10 $=1.10 \mathrm{E}-02$ (Garbero et al. 2012), As $=3.00 \mathrm{E}-04$ (US EPA 2016), $\mathrm{Cd}=1.00 \mathrm{E}-03$ (Yang et al. 2016), $\mathrm{Ni}=2.06 \mathrm{E}-02$ (Taiwo et al. 2016), $\mathrm{Pb}=3.52 \mathrm{E}-03$ (Taiwo et al. 2016), $\mathrm{NO}_{2}=1.10 \mathrm{E}-02$ (Garbero et al. 2012), $\mathrm{C}_{6} \mathrm{H}_{6}=4.00 \mathrm{E}-03$ (US EPA 2016).

\subsubsection{Combined carcinogenic and non-carcinogenic risk rates}

To estimate the total carcinogenic risk (Rt) of the inhalation of many pollutants at the same time, the sums of separate risk rate values were calculated, in accordance with equitation (4).

$\mathrm{Rt}=\mathrm{R}_{1}+\mathrm{R}_{2}+\ldots+\mathrm{R}_{\mathrm{n}}$

To estimate the total non-carcinogenic risk of the inhalation of many pollutants at the same time, the hazard index (HI) parameter was used. It was calculated in accordance with equitation (5) (US EPA 2007):

$\mathrm{HI}=\mathrm{HQ}_{1}+\mathrm{HQ}_{2}+\ldots+\mathrm{HQ}_{\mathrm{n}}$

where 1-n: specified pollutants in the air.

\section{Results and discussion}

\subsection{Estimated daily intake}

Our daily intake rates, calculated from inhalation exposure (Table 2), indicated that the rates were higher in the case of women as compared to men. Based on the allowed values, specified in the Polish Regulation of the Minister of the Environment concerning the levels of certain substances in the air of 24 August 2012 (published in Dz.U. 2012, Item 1031) (see Table 1), the maximum safe intake rates were calculated. It was found that the actual intake of polluted air inhaled by adults, children, and infants was higher than the maximum safe rates identified at the locations of all monitoring stations for PM10 and BaP (however, the BaP measurements were conducted at 2 stations only). The 


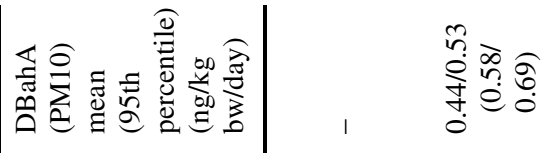

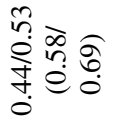

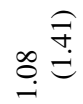

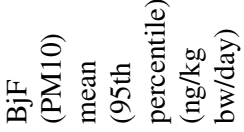

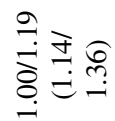

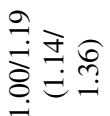

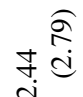

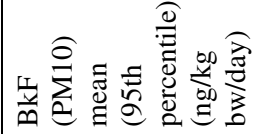

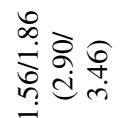

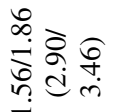
$\stackrel{\infty}{\stackrel{\infty}{\infty}}$

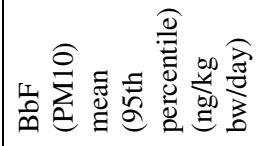
离守

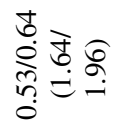

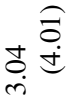

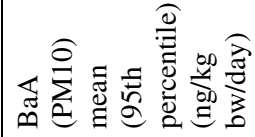

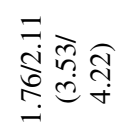

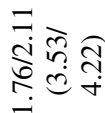

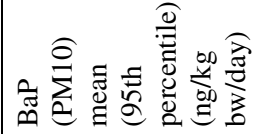

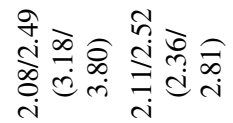

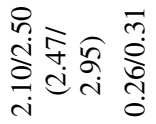

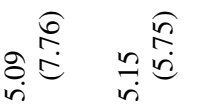

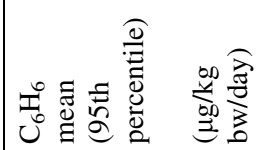

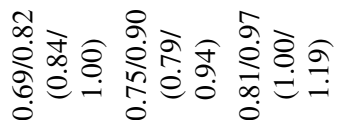

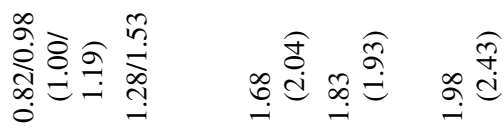

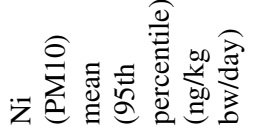

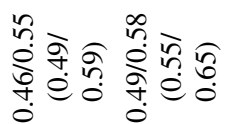

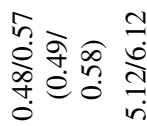

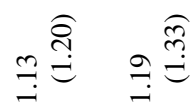

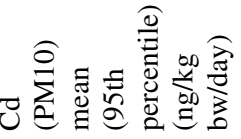

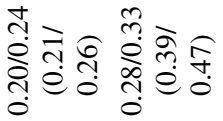

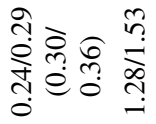
f)

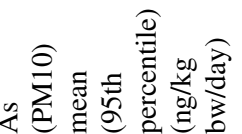

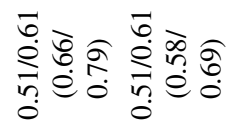

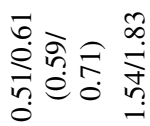

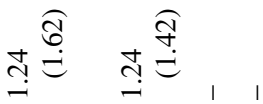

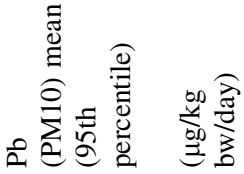

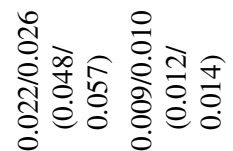

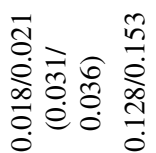

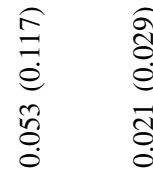

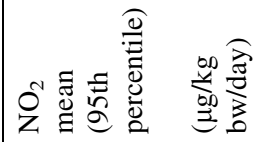

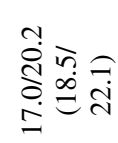

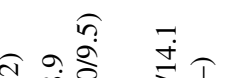

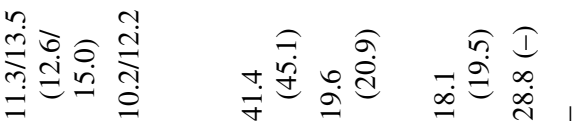

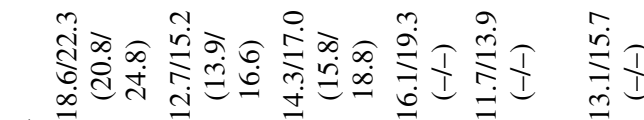

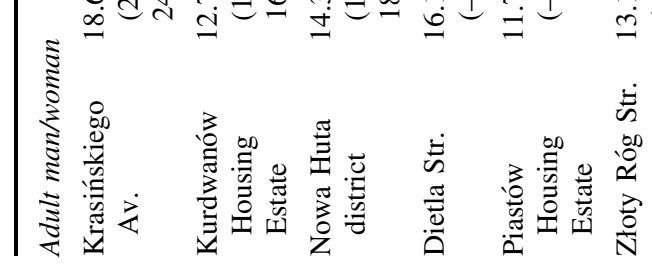

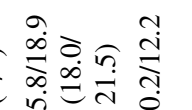

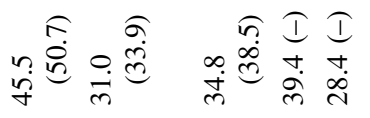

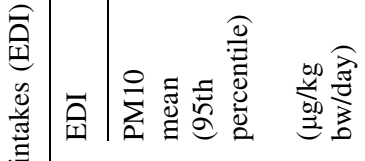

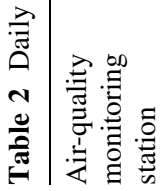




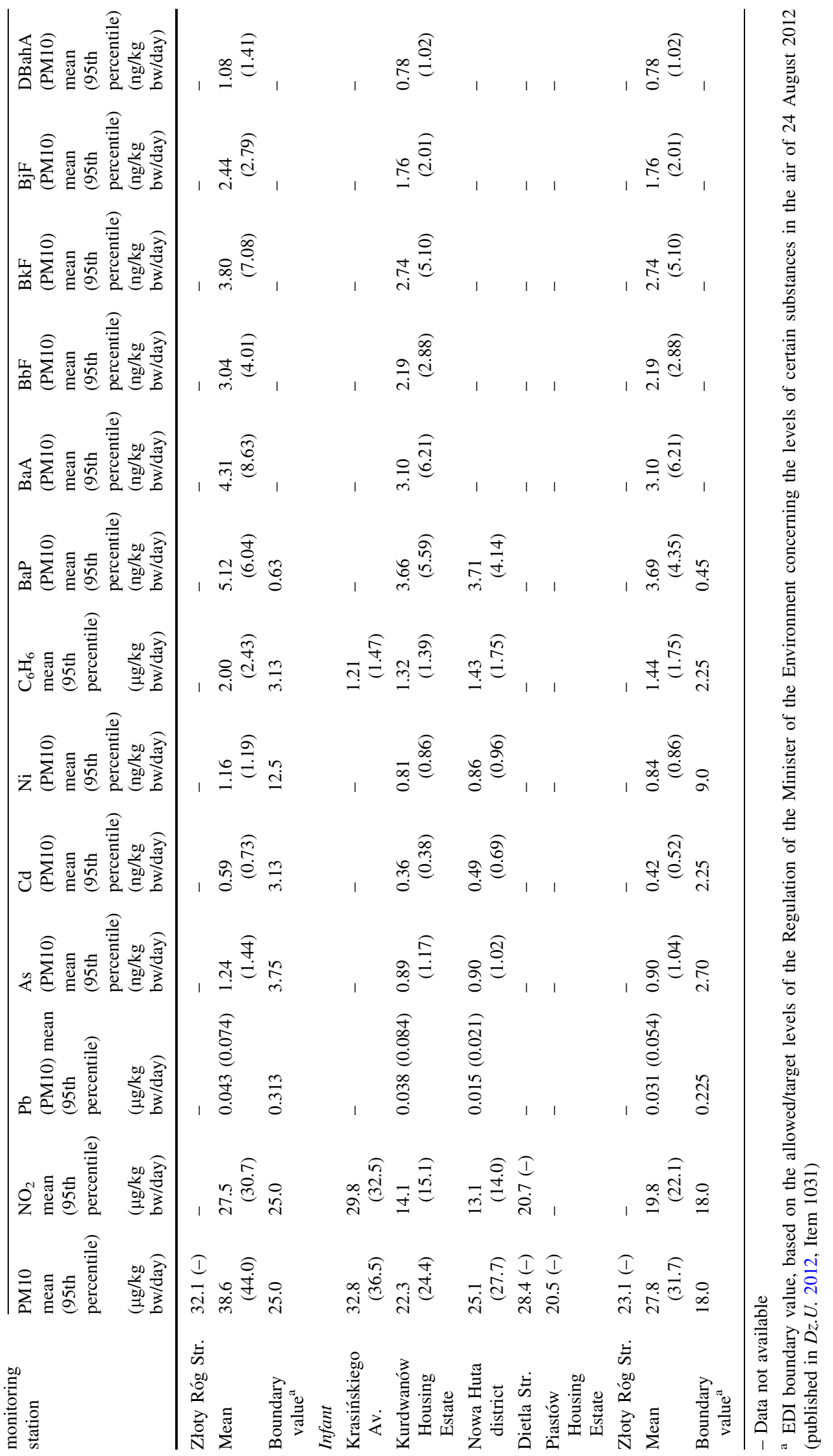


excess of the allowed daily intake rate for PM10 occurred with the highest value in the case of children (maximum by $20.5 \mu \mathrm{g} / \mathrm{kg}$ bw per day), infants (maximum by 14.8), women by 10.1 , and men by $8.4 \mu \mathrm{g} / \mathrm{kg}$ bw per day. Calculated in our research EDI values correspond with limited publications on effects on respiratory morbidity of children (Gouveia and Fletcher 2000; Villeneuve et al. 2007). The highest excesses of PM10 were determined for the pollution concentrations at the Krasińskiego Av. station. In the case of $\mathrm{NO}_{2}$, excess values of the allowed daily intake rate was found at the Krasińskiego Av. and Dietla Str. stations. No such excess, however, was found in the cases of $\mathrm{Pb}, \mathrm{As}$, $\mathrm{Cd}, \mathrm{Ni}$, and $\mathrm{C}_{6} \mathrm{H}_{6}$. We should mention here, that the evaluation of the risk concerning trace elements was based only on the measurements of PM10 contents, without taking into account the remaining dust fractions or actual inhaled dust quantities. As to the remaining polycyclic aromatic hydrocarbons (PAH) monitored in the air, the said Polish Regulation does not specify the allowed values, although the relevant concentrations were similar to those of $\mathrm{BaP}$. When analysing the intake rates calculated for the mean values of particular types of pollution in Kraków, it was found that the daily intake rate was higher than the maximum safe rate, in the case of PM10 by 55\% higher among adults and 54\% among children and infants, while that of $\mathrm{NO}_{2}$ was by $11 \%$ higher among adults and $10 \%$ among children and infants. In the case of $\mathrm{BaP}$, the excess of the maximum safe daily rate amounted to $773 \%$ among men, $806 \%$ among women, $813 \%$ among children, and $820 \%$ among infants.

\subsection{Carcinogenic risk of outdoor air inhalation}

Based on the calculated intake rates and taking into account the Slope Factor (SF) values (see Sect. 2.2.2 above), carcinogenic risk rates $(\mathrm{R})$ were calculated. Various levels of carcinogenic risk have been adopted in different countries, based on the still ongoing modifications of the methodology, however in practice of many countries the risk level values from $1.00 \mathrm{E}-04$ to $1.00 \mathrm{E}-06$ are acceptable. It means that there is the social approval for the one additional case of cancer from per 1000 to per 10,000 people in studied population, depending on the country. Moreover, the risk level of $1.00 \mathrm{E}-03$ is definitely unacceptable and such a situation requires corrective actions intended to reduce that level. Since no inhalation-exposure risk-estimation procedure has been implemented in Poland and we do not have legally determined acceptable risk levels, this study assumes, relying on a conservative risk estimation, one additional case of cancer occurrence in the population of one million people (1.00E-06) as an acceptable risk level.

Unacceptable risk levels were found in our research on carcinogenic pollution in the cases of $\mathrm{As}(\mathrm{PM} 10)$,
$\mathrm{Cd}(\mathrm{PM} 10), \mathrm{C}_{6} \mathrm{H}_{6}, \mathrm{BaP}, \mathrm{BaA}, \mathrm{BbF}, \mathrm{BkF}, \mathrm{BjF}$, and DBahA among adults, children, and infants at all the monitoring stations that tested the respective pollution types (Table 3 ). However, in case of the last five mentioned pollutants the measurements were made only at one monitoring station (Kurdwanów Housing estate). Calculated in our research carcinogenic risk values correspond to studies of Cohen (2000) and Vineis et al. (2004), who points the role of above mentioned air pollutants in lung cancer occurrence. An unacceptable risk level was also found for $\mathrm{Pb}$ at the Kurdwanów Housing Estate station in the case of children, infants, and women: $2.23 \mathrm{E}-06,1.61 \mathrm{E}-06$, and $1.09 \mathrm{E}-06$, respectively. The highest mean carcinogenic risk values for the city of Kraków were found in the following sequence: among men: $\mathrm{C}_{6} \mathrm{H}_{6}$ : 8.19E-05, BaP: 8.18E-06, $\mathrm{As}(\mathrm{PM} 10)$ : 6.12E-06, $\mathrm{Cd}(\mathrm{PM} 10): 3.61 \mathrm{E}-06, \mathrm{~Pb}(\mathrm{PM} 10): 7.42 \mathrm{E}-07$, and $\mathrm{Ni}(\mathrm{PM} 10): 4.33 \mathrm{E}-07$; women: $\mathrm{C}_{6} \mathrm{H}_{6}: 9.79 \mathrm{E}-05$, BaP: 9.77E-06, As(PM10): 7.30E-06, Cd(PM10): 4.31E-06, $\mathrm{Pb}$ (PM10): 8.86E-07 and Ni(PM10): 5.18E-07; children: $\mathrm{C}_{6} \mathrm{H}_{6}: 2.00 \mathrm{E}-04$, BaP: 2.00E-05, As(PM10): 1.49E-05, Cd(PM10): $\quad 8.81 \mathrm{E}-06, \quad \mathrm{~Pb}(\mathrm{PM} 10): \quad 1.81 \mathrm{E}-06, \quad$ and $\mathrm{Ni}(\mathrm{PM} 10)$ : $1.06 \mathrm{E}-06$; and infants: $\mathrm{C}_{6} \mathrm{H}_{6}: 1.44 \mathrm{E}-04, \mathrm{BaP}$ : 1.44E-05, As(PM10): 1.07E-05, Cd(PM10): 6.35E-06, $\mathrm{Pb}$ (PM10):1.30E-06, and Ni(PM10): 7.62E-07.

We should emphasize that the calculated carcinogenic risk values do not entail all types of pollution because not all pollutants are tested at the monitoring stations. Besides, the SF values may not be available for all the stations in the toxicological databases, and those are indispensable for the relevant calculations.

\subsection{Non-carcinogenic risk of outdoor air inhalation}

Based on the calculated intake rates and taking into account the reference values of RfD doses (see Sect. 2.2.3 above), hazard quotient (HQ) values were calculated. Non-carcinogenic risk means all adverse health effects in the organism, excluding cancer, caused by exposure factors. The allowed non-carcinogenic risk is such for which $\mathrm{HQ}<1$. However, if $\mathrm{HQ}>1$, health risk appears and is the larger the higher numerical value is attained by HQ (Lemly 1996). The values of HQ $>1$ determine unacceptable risk, and, in such cases, it is definitely necessary to implement corrective actions intended to reduce the risk level.

Medium risk level was established at all the monitoring stations in Kraków for the non-carcinogenic pollutants tested, in the case of adults, children, and infants, in respect of the exposure to inhalation of PM10. For $\mathrm{NO}_{2}$ the risk was medium in the case of children and infants, and for adults in the case of Krasińskiego Av. and Dietla Str. stations (Table 4). The calculated risk was low at all the monitoring stations in the case of adults, children, and infants for $\mathrm{C}_{6} \mathrm{H}_{6}$, as well as, in case of adults at 


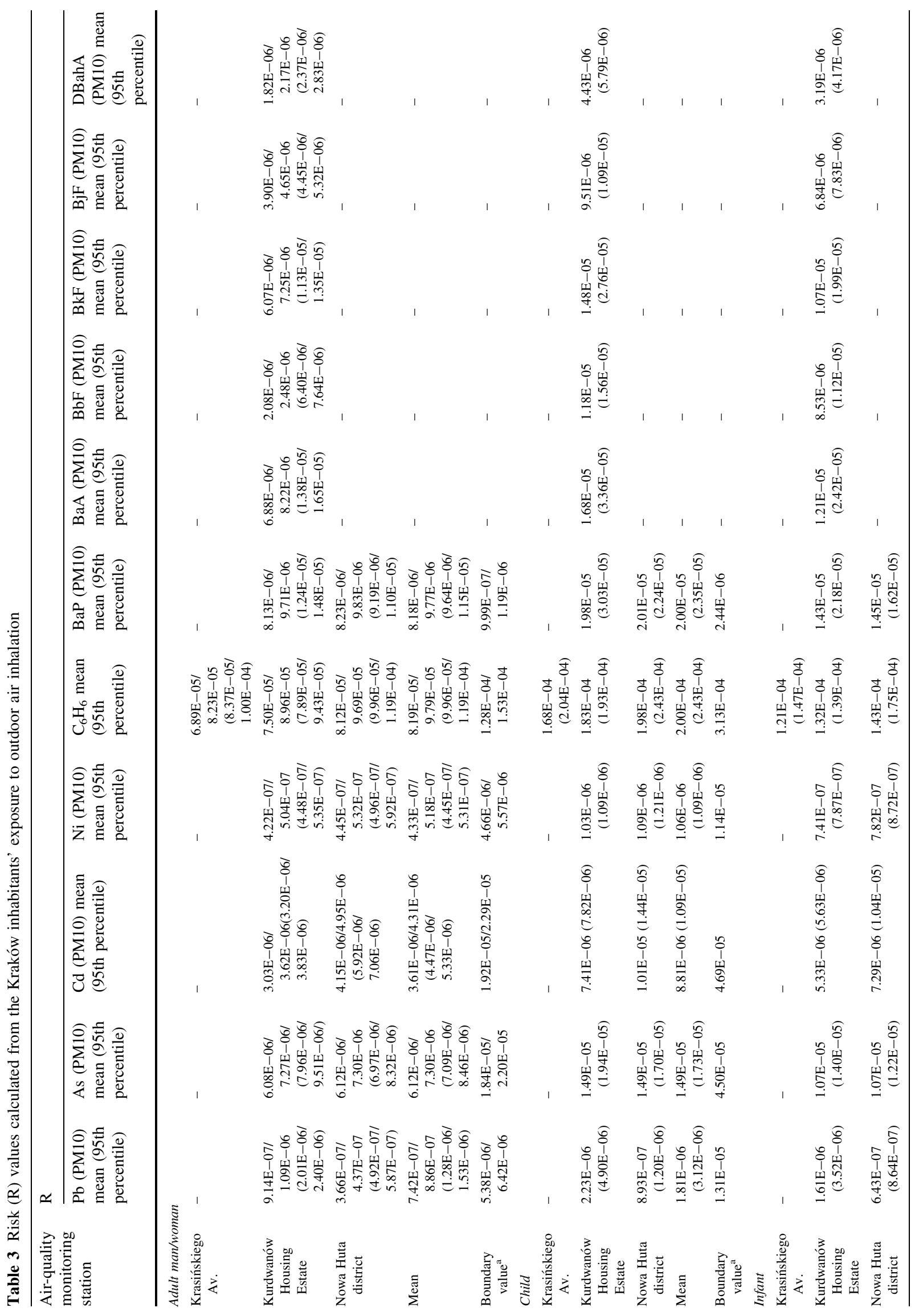




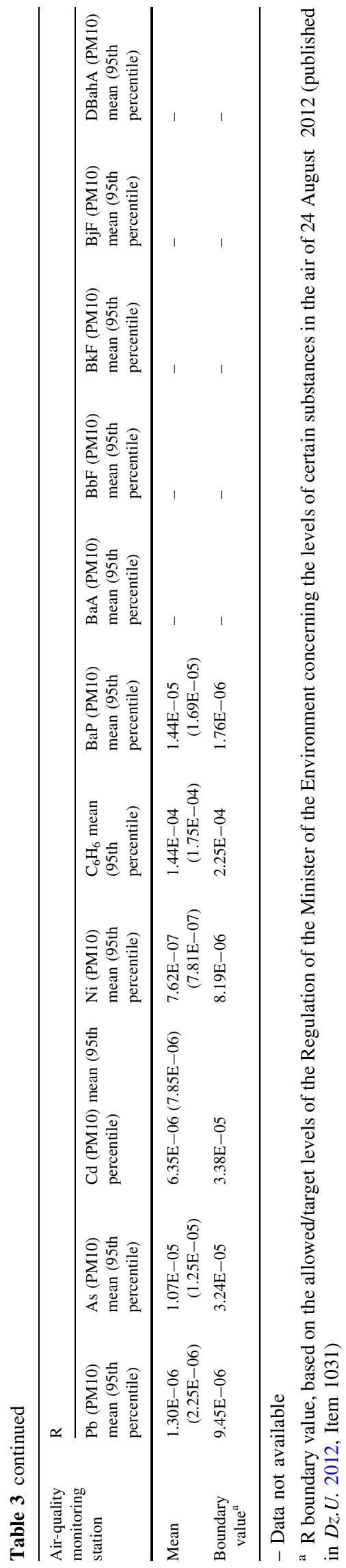

Kurdwanów Housing Estate and Nowa Huta district stations. The non-carcinogenic risk rates for all the six stations in Kraków relating to PM10 amounted to 1.44 (men), 1.72 (women), 3.51 (children), and 2.53 (infants). In the case of $\mathrm{NO}_{2}$, the values were 1.02, 1.22, 2.50, 1.80, respectively; and for $\mathrm{C}_{6} \mathrm{H}_{6}: 0.205,0.245,0.5$, and 0.36 , respectively. Calculated results indicate the necessity of detailed investigations in Kraków as D’Amato et al. (2002) stated the dependence between increase of respiratory allergic diseases and increase of outdoor air pollution.

We should mention that the calculated non-carcinogenic risk rates do not entail all the types of pollution, because not all of them are measured at the monitoring stations, or otherwise the RfD toxicological parameters may not be available at all the stations. Such values are, however, required for calculations.

\subsection{Combined carcinogenic and non-carcinogenic risks}

The total value of carcinogenic (Rt) and non-carcinogenic (HI) risk is presented in Table 5. The highest total value of the carcinogenic risk (Rt) for all the six stations in Kraków, resulting from inhalation exposure to polluted air, was determined in respect of children (3.04E-04), followed by infants (2.22E-04), women (1.45E-04), and men (1.22E-04). In all the subpopulations, the values exceeded the acceptable risk levels. When analysing the total carcinogenic risk at particular air-quality monitoring stations, it was found that risk was the highest, in respect of all the subpopulations, at Kurdwanów Housing Estate, followed by Nowa Huta district, and Krasińskiego Av.

The highest total value of the non-carcinogenic risk (HI) for all the six stations in Kraków, resulting from inhalation exposure to polluted air, was determined, similarly to carcinogenic risk figures, in the following sequence: children (6.53), infants (4.70), women (3.19), and men (2.67). In all the subpopulations, the HI value indicated medium risk level related to non-carcinogenic pollution exposure. When analysing total non-carcinogenic risk at particular air-quality monitoring stations, it was found that the risk was the highest, in respect of all the subpopulations, at the station located at Krasińskiego Av., followed by those at Dietla Str., Nowa Huta district, Kurdwanów Housing Estate, Złoty Róg Str., and Piastów Housing Estate.

We should mention that the calculated risk values are certainly underestimated. That may be due to several reasons. First of all, not all the pollutants are tested by the Regional Environmental Protection Inspectorate systems and each pollutant may not be tested by all the monitoring stations. Consequently, we obtain only general data, as it is the case of dust, for which the PM10 and PM2.5 fraction concentrations are tested, but no toxicological data are 


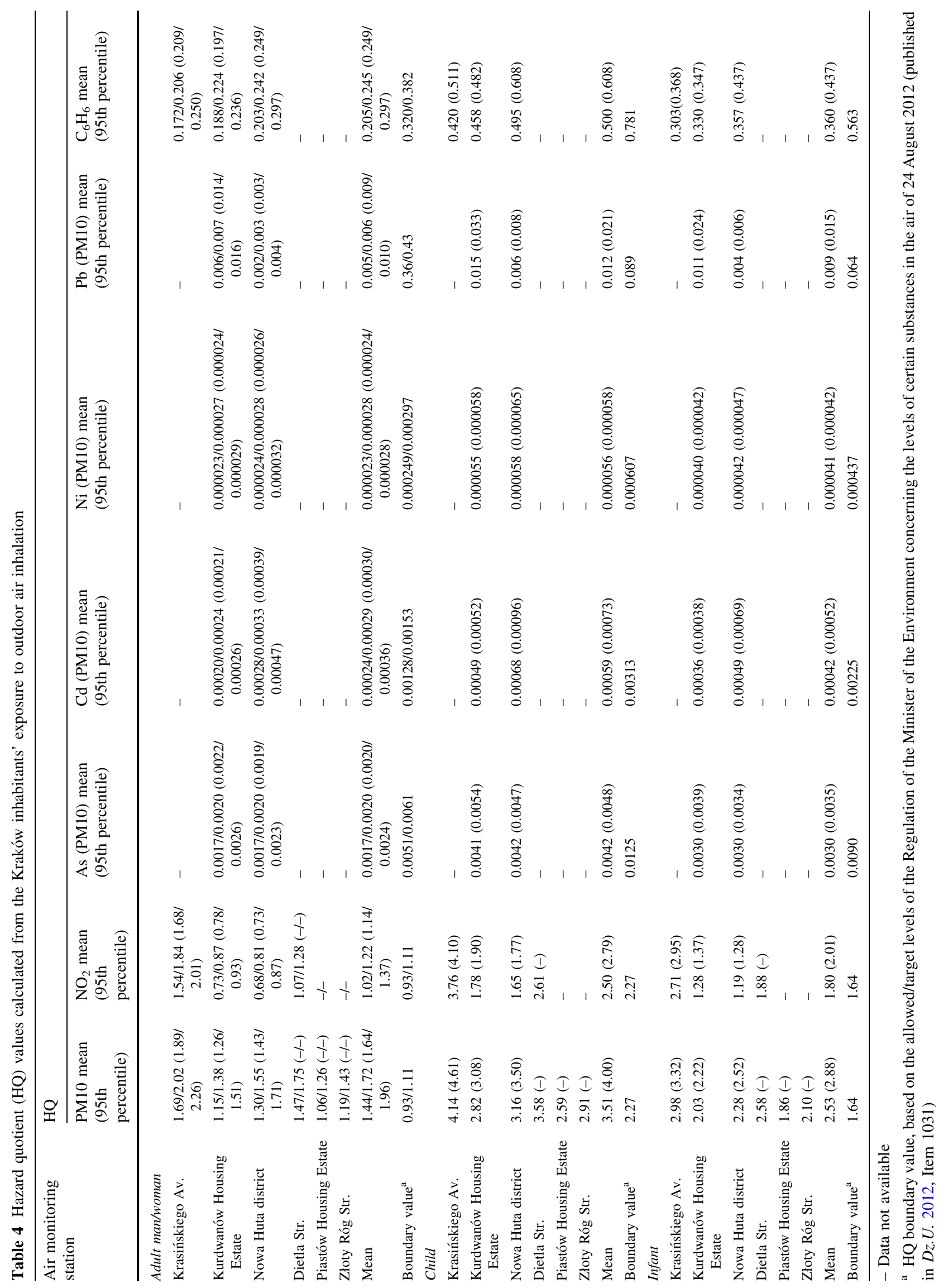


Table 5 Total risk (Rt) values and hazard indices (HI) relating to the Kraków inhabitants' exposure to outdoor air inhalation

\begin{tabular}{|c|c|c|c|c|}
\hline \multirow[t]{2}{*}{ Air monitoring station } & \multicolumn{2}{|l|}{ Rt } & \multicolumn{2}{|l|}{$\mathrm{HI}$} \\
\hline & Mean & 95th percentile & Mean & 95th percentile \\
\hline \multicolumn{5}{|l|}{ Adult man/woman } \\
\hline Krasińskiego Av. & $6.89 \mathrm{E}-05 / 8.23 \mathrm{E}-05$ & $8.37 \mathrm{E}-05 / 1.00 \mathrm{E}-04$ & $3.41 / 4.07$ & $3.78 / 4.51$ \\
\hline Kurdwanów Housing Estate & $1.14 \mathrm{E}-04 / 1.37 \mathrm{E}-04$ & $1.43 \mathrm{E}-04 / 1.71 \mathrm{E}-04$ & $2.08 / 2.48$ & $2.26 / 2.69$ \\
\hline Nowa Huta district & $1.00 \mathrm{E}-04 / 1.20 \mathrm{E}-04$ & $1.23 \mathrm{E}-04 / 1.46 \mathrm{E}-04$ & $2.18 / 2.60$ & $2.41 / 2.88$ \\
\hline Dietla Str. & $-1-$ & $-1-$ & $2.54 / 3.03$ & $-1-$ \\
\hline Piastów Housing Estate & $-1-$ & $-1-$ & $1.06 / 1.26$ & $-1-$ \\
\hline Złoty Róg Str. & $-1-$ & $-1-$ & $1.19 / 1.43$ & $-1-$ \\
\hline Mean & $1.22 \mathrm{E}-04 / 1.45 \mathrm{E}-04$ & $1.61 \mathrm{E}-04 / 1.92 \mathrm{E}-04$ & $2.67 / 3.19$ & $3.04 / 3.63$ \\
\hline \multicolumn{5}{|l|}{ Child } \\
\hline Krasińskiego Av. & $1.68 \mathrm{E}-04$ & $2.04 \mathrm{E}-04$ & 8.32 & 9.22 \\
\hline Kurdwanów Housing Estate & $2.86 \mathrm{E}-04$ & $3.50 \mathrm{E}-04$ & 5.07 & 5.50 \\
\hline Nowa Huta district & $2.45 \mathrm{E}-04$ & $2.99 \mathrm{E}-04$ & 5.32 & 5.89 \\
\hline Dietla Str. & - & - & 6.19 & - \\
\hline Piastów Housing Estate & - & - & 2.59 & - \\
\hline Złoty Róg Str. & - & - & 2.91 & - \\
\hline Mean & $3.04 \mathrm{E}-04$ & $3.92 \mathrm{E}-04$ & 6.53 & 7.43 \\
\hline \multicolumn{5}{|l|}{ Infant } \\
\hline Krasińskiego Av. & $1.21 \mathrm{E}-04$ & $1.47 \mathrm{E}-04$ & 5.99 & 6.64 \\
\hline Kurdwanów Housing Estate & $2.06 \mathrm{E}-04$ & $2.52 \mathrm{E}-04$ & 3.65 & 3.96 \\
\hline Nowa Huta district & $1.77 \mathrm{E}-04$ & $2.15 \mathrm{E}-04$ & 3.83 & 4.24 \\
\hline Dietla Str. & - & - & 4.46 & - \\
\hline Piastów Housing estate & - & - & 1.86 & - \\
\hline Złoty Róg Str. & - & - & 2.10 & - \\
\hline Mean & $2.22 \mathrm{E}-04$ & $2.83 \mathrm{E}-04$ & 4.70 & 5.35 \\
\hline
\end{tabular}

- Data not available

available in respect of the pollutants that are currently the most serious (Marzouni et al. 2016). Thus, risk estimations are not feasible. The situation is worse when specific types of pollution are not subjected to the standards adopted by legal regulations concerning air quality.

It also should be emphasised that between various exposure factors interactions exist when the total risk is analysed (Heng et al. 2008). Moreover, in case of the air different meteorological relationships may occur that will affect the final risk value (Jerrett et al. 2007; Tan et al. 2016). However, except mean concentrations of selected pollutant measured in the six air-quality monitoring stations, no other information were available. This only points the lack of very important information to need to be analysed in the best interest of inhabitants.

The knowledge of the chemical and mineralogical composition of the deposited dust under discussion is also indispensable for a comprehensive evaluation of risk and determination of possible negative health effects (Hofmann 2000). As mentioned by Dziugieł et al. (2012), the data concerning dust concentration in a cubic metre of air are of paramount importance because they allow to determine the actual quantities of inhaled particulate matter.

Another failure of adequate determination of risk values for particular places results from the fact that the airquality monitoring stations are distributed only over six locations in Kraków. Consequently, the results obtained at those stations have to serve fairly large areas and they may not be adequate for particular places subjected to investigation (Bayraktar et al. 2005).

Another issue concerns lack of measurements of specific types of pollutants and of their concentrations indoors. Presently, calculations refer to atmospheric air pollution concentration values. However, people spend most of their time rather indoors (mainly at work and at home), where pollution and pollutant concentrations are different than those outdoors (Guo et al. 2004). Therefore, determination of people's time of staying outdoors and indoors, as well as the types of pollution and pollution concentration would allow to obtain much more realistic risk estimations.

It is also essential to characterise the investigated populations accurately, with e.g. determination of actual 
population parameters (Ma 2000). The following parameters would be essential for the determination of inhalation exposure: age, body weight, lung surface area, health condition and life style (including e.g. smoking or exercise), and the time of staying indoors and outdoors. Such data can significantly change the values of the calculated risk either way.

Because all of the above mentioned information have to be analysed at the same time there is the necessity of usage of the appropriate statistical modelling. Such research are popular worldwide using advanced statistical modelling (Kaya and Kahraman 2009; Bartoletti and Loperfido 2010; Yu et al. 2011; Chien and Bangdiwala 2012; Wang and Chen 2015; Benis et al. 2016). Unfortunately in Poland such research have not been performed yet. Actual health risk values are so essential because human health and life are of paramount importance, and, on the other hand, once the allowed risk parameters are exceeded, it will be necessary to implement expensive corrective actions designed to reduce the risk rates down to acceptable levels.

\section{Conclusions}

The risk assessment presented in this paper has been formulated only as an estimation owing to incomplete data. Still, it demonstrates that the existing health risk results from inhalation exposure to polluted air affecting the residents of Kraków, and the estimated risk rates are claimed to be rather underestimated.

Unacceptable risk levels were identified for specific carcinogenic types of pollution in respect of all the studied subpopulations, under the formula of $\mathrm{C}_{6} \mathrm{H}_{6}>\mathrm{BaP}>$ $\mathrm{As}(\mathrm{PM} 10)>\mathrm{Cd}(\mathrm{PM} 10)>\mathrm{Pb}(\mathrm{PM} 10)>\mathrm{Ni}(\mathrm{PM} 10)$. The total carcinogenic risk $(\mathrm{Rt})$ rates were estimated for the following residents of Kraków: children: 3.04E-04, infants 2.22E-04, women: $1.45 \mathrm{E}-04$, and men: $1.22 \mathrm{E}-04$. The risk rate was the highest at the air-quality monitoring station located at os. Kurdwanów, followed by those of Nowa Huta district and Krasińskiego Av.

Medium risk level was established at all the monitoring stations for the non-carcinogenic pollutants tested, in the case of adults, children, and infants, in respect of inhalation exposure to PM10. For $\mathrm{NO}_{2}$ the risk was medium in the case of children and infants, and for adults in the case of Krasińskiego Av. and Dietla Str. stations. The calculated risk was low at all the monitoring stations in the case of adults, children, and infants for $\mathrm{C}_{6} \mathrm{H}_{6}$, as well as, in case of $\mathrm{NO}_{2}$ for adults at Kurdwanów Housing Estate and Nowa Huta district stations.

The total risk (HI) of non-carcinogenic substances was rated medium and ranged as follows: 6.53 for children, 4.70 for infants, 3.19 for women, and 2.67 for men. That type of risk was decreasing in the sequence of the following station locations: Krasińskiego Av. $>$ Dietla Str. $>$ Nowa Huta district $>$ Kurdwanów Housing Estate $>$ Złoty Róg Str. $>$ Piastów Housing Estate.

This paper further indicates what types of data would be required to obtain from the air-quality monitoring system for the health risk evaluation procedures as realistic as possible. The health risk assessment procedures have a good chance to be implemented as health protection tools. Consequently, the corrective action plans adopted on the basis of such procedures will be able to improve the air quality in Kraków which is something the residents really expect and care for.

Acknowledgements This research was supported within the framework of Statutory Research Grant No. 11.11.140.199 and Dean's Grant No. 15.11.140.357 by the AGH University of Science and Technology.

Open Access This article is distributed under the terms of the Creative Commons Attribution 4.0 International License (http://creativecommons.org/licenses/by/4.0/), which permits unrestricted use, distribution, and reproduction in any medium, provided you give appropriate credit to the original author(s) and the source, provide a link to the Creative Commons license, and indicate if changes were made.

\section{References}

Adamiec E, Jarosz-Krzemińska E, Wieszała R (2016) Heavy metals from non-exhaust vehicle emissions in urban and motorway road dusts. Environ Monit Assess 188:369. doi:10.1007/s10661-016$5377-1$

ATSDR (2005) Public health assessment guidance manual, Agency for Toxic Substances and Disease Registry

Bartoletti S, Loperfido N (2010) Modelling air pollution data by the skew-normal distribution. Stoch Environ Res Risk Assess 24(4):513-517. doi:10.1007/s00477-009-0341-z

Bayraktar H, Turalioglu FS, Tuncel G (2005) A Kriging-based approach for locating a sampling site-in the assessment of air quality. Stoch Environ Res Risk Assess 19:301-305. doi:10. 1007/s00477-005-0234-8

Beig G, Chate DM, Ghude SD et al (2013) Quantifying the effect of air quality control measures during the 2010 Commonwealth Games at Delhi, India. Atmos Environ 80:455-463

Benis KZ, Fatehifar E, Shafiei S et al (2016) Design of a sensitive air quality monitoring network using an integrated optimization approach. Stoch Environ Res Risk Assess 30:779-793. doi:10. 1007/s00477-015-1189-z

Brook RD, Franklin B, Cascio W et al (2004) Air pollution and cardiovascular disease. Circulation 109:2655-2671

Brunekreef B, Holgate ST (2002) Air pollution and health. Lancet 360:1233-1242

CalEPA (2016) Office of environmental health hazard assessment assessments. California Environmental Protection Agency, Office of Environmental Health Hazard Assessment, Oakland, CA. http://oehha.ca.gov/chemicals

Chien LC, Bangdiwala SI (2012) The implementation of Bayesian structural additive regression models in multi-city time series air pollution and human health studies. Stoch Environ Res Risk Assess 26(8):1041-1051. doi:10.1007/s00477-012-0562-4 
China names 10 most polluted cities (2015). www.chinadaily.com.cn/ agencies. Accessed 2 Feb 2015

Cohen AJ (2000) Outdoor air pollution and lung cancer. Environ Health Perspect 108(4):743-750

D'Amato G, Liccardi G, D'Amato M, Cazzola M (2002) Outdoor air pollution, climatic changes and allergic bronchial asthma. Eur Respir J 20:763-776. doi:10.1183/09031936.02.00401402

Dziugieł M, Bogacki M, Oleniacz R, Mazur M (2012) Zawartość węgla i siarki w pyle PM2.5 i PM10 w powietrzu w centrum Krakowa. In: Konieczyński J (ed) Ochrona powietrza w teorii i praktyce, vol 1. Instytut Podstaw Inżynierii Środowiska PAN, Zabrze, pp 29-41

EEA (2015) Air quality in Europe-2015 report. European Environment Agency, EEA Report No 5/2015. doi: 10.2800/62459

Garbero V, Montaldo A, Lazovic N et al (2012) The impact of the urban air pollution on the human health: a case study in Turin. Air Pollution Modelling and its Application XXI. Springer, Dordrecht, pp 729-732

Gemenetzis P, Moussas P, Arditsoglou A, Samara C (2006) Mass concentration and elemental composition of indoor PM2.5 and PM10 in University rooms in Thessaloniki, northern Greece. Atmos Environ 17:3195-3206

Gouveia N, Fletcher T (2000) Respiratory diseases in children and outdoor air pollution in São Paulo, Brazil: a time series analysis. Occup Environ Med 57(7):477-483. doi:10.1136/oem.57.7.477

Guo H, Lee SC, Chan LY, Li WM (2004) Risk assessment of exposure to volatile organic compounds in different indoor environments. Environ Res 1:57-66

Haining R, Law J, Maheswaran R et al (2007) Bayesian modelling of environmental risk: example using a small area ecological study of coronary heart disease mortality in relation to modelled outdoor nitrogen oxide levels. Stoch Environ Res Risk Assess 21(5):501-509. doi:10.1007/s00477-007-0134-1

Heng L, Li HL, Huang GH, Zou Y (2008) An integrated fuzzystochastic modeling approach for assessing health-impact risk from air pollution. Stoch Environ Res Risk Assess 22(6):789-803. doi:10.1007/s00477-007-0187-1

Hofmann W (2000) Stochastic dose estimation for inhaled particulates. Stoch Environ Res Risk Assess 14(3):181-193. doi:10. 1007/s004770000037

Ma HW (2000) The incorporation of stochasticity in risk and management: a case study. Stoch Environ Res Risk Assess 14:195-206. doi:10.1007/PL00009781

Indulski JA, Rolecki R (1995) Industrialization and environmental health in Poland. Cent Eur J Public Health 3(1):3-12

Iwai K, Mizuno S, Miyasaka Y, Mori T (2005) Correlation between suspended particles in the environmental air and causes of disease among inhabitants: cross-sectional studies using the vital statistics and air pollution data in Japan. Environ Res 99:106-117

Jędrychowski W (2000) Environmental respiratory health in central and eastern Europe. Cent Eur J Public Health 8(1):33-39

Jędrychowski W, Flak E, Mróz E (1997) Atmospheric air pollution as a factor potentiating the risk of asthma in school children. Epidemiologic studies in Krakow. Przegl Lek 54(3):158-162

Jędrychowski W, Wojtyniak B, Szafraniec K, Goryński P (2003) Trends in hospitalization rates form asthma in children and adolescents in Poland. Prz Epidemiol 57(4):663-670

Jędrychowski W, Maugeri U, Jędrychowska-Bianchi I, Flak E (2005) Effect of indoor air quality in the postnatal period on lung function in pre-adolescent children: a retrospective cohort study in Poland. Public Health 119:535-541

Jędrychowski W, Perera FP, Spengler JD et al (2013) Intrauterine exposure to fine particulate matter as a risk factor for increased susceptibility to acute broncho-pulmonary infections in early childhood. Int J Hyg Environ Health 216:395-401
Jędrychowski W, Perera F, Maugeri U et al (2015) Long term effects of prenatal and postnatal airborne PAH exposures on ventilatory lung function of non-asthmatic preadolescent children. Prospective birth cohort study in Krakow. Sci Total Environ 502:502-509

Jerrett M, Newbold KB, Burnett RT et al (2007) Geographies of uncertainty in the health benefits of air quality improvements. Stoch Environ Res Risk Assess 21(5):511-522. doi:10.1007/ s00477-007-0133-2

Jiming HAO, Kebin HE, Duan L et al (2007) Air pollution and its control in China. Front Environ Sci Eng China 1(2):129-142. doi:10.1007/s11783-007-0024-2

Kan H, Chen R, Tong S (2012) Ambient air pollution, climate change and population health in China. Environ Int 42:10-19

Katsouyanni K, Schwartz J, Spix C et al (1996) Short-term effects of air pollution on health: a European approach using epidemiologic time series data: the APHEA protocol. J Epidemiol Community Health 50(1):12-18

Katsouyanni K, Touloumi G, Spix C et al (1997) Short-term effects of ambient sulphur dioxide and particulate matter on mortality in 12 European cities: results from time series data from the APHEA project. Br Med J 314:1658-1663

Katsouyanni K, Touloumi G, Samoli E et al (2001) Confounding and effect modification in the short-term effects of ambient particles on total mortality: results from 29 European cities within the APHEA2 project. Epidemiology 12:521-531

Kaya I, Kahraman C (2009) Fuzzy robust process capability indices for risk assessment of air pollution. Stoch Environ Res Risk Assess 23(4):529-541. doi:10.1007/s00477-008-0238-2

Krzyżanowski M, Wojtyniak B (1991) Air pollution and daily mortality in Kraków. Public Health Rev 19:73-81

Lemly AD (1996) Evaluation of the hazard quotient method for risk assessment of selenium. Ecotox Environ Safe 35:156-162

Lippmann M, Chen LC, Gordon T et al (2013) National Particle Component Toxicity (NPACT) initiative: integrated epidemiologic and toxicologic studies of the health effects of particulate matter components. Res Rep Health Eff Inst 177:5-13

López A, Yusà V, Muñoz A et al (2017) Risk assessment of airborne pesticides in a Mediterranean region of Spain. Sci Total Environ 574:724-734

Lu S, Yao Z, Chen X et al (2008) The relationship between physicochemical characterization and the potential toxicity of fine particulates (PM2.5) in Shanghai atmosphere. Atmos Environ 42:7205-7214

Marzouni MB, Alizadeh T, Banafsheh MR et al (2016) A comparison of health impacts assessment for PM10 during two successive years in the ambient air of Kermanshah, Iran. Atmos Pollut Res 7:768-774

Morelli X, Rieux C, Cyrys J et al (2016) Air pollution, health and social deprivation: a fine-scale risk assessment. Environ Res 147:59-70

Munir S, Gabr S, Habeebullah TM, Janajrah MA (2016) Spatiotemporal analysis of fine particulate matter (PM2.5) in Saudi Arabia using remote sensing data. Egypt J Remote Sens Space Sci. doi:10.1016/j.ejrs.2016.06.001

Oeder S, Dietrich S, Weichenmeier I et al (2012) Toxicity and elemental composition of particulate matter from outdoor and indoor air of elementary schools in Munich, Germany. Indoor Air 22:148-158

Oettl D, Almbauer R, Sturm P et al (2003) Dispersion modelling of air pollution caused by road traffic using a Markov Chain-Monte Carlo model. Stoch Environ Res Risk Assess 17(1):58-75. doi:10.1007/s00477-002-0120-6

Oleniacz R, Bogacki M, Szulecka A et al (2016a) Wpływ prędkości i kierunku wiatru na jakość powietrza w Krakowie, In: Dziopak J, Słyś D, Stec A (eds) V Międzynarodowa Konferencja Naukowo- 
Techniczna INFRAEKO 2016 Nowoczesne miasta. Infrastruktura i środowisko. Oficyna Wydawnicza Politechniki Rzeszowskiej, Rzeszów-Kraków, pp 263-276

Oleniacz R, Bogacki M, Szulecka A et al (2016b) Assessing the impact of wind speed and mixing-layer height on air quality in Krakow (Poland) in the years 2014-2015. J Civ Eng Environ Archit JCEEA 33(63 (2/II/16)):315-342

Oudinet JP, Méline J, Chełmicki W et al (2006) Towards a multidisciplinary and integrated strategy in the assessment of adverse health effects related to air pollution: the case study of Kraków (Poland) and asthma. Environ Pollut 143:278-284

Pant P, Guttikunda SK, Peltier RE (2016) Exposure to particulate matter in India: a synthesis of findings and future directions. Environ Res 147:480-496

Peters A, Dockery DW, Muller JE, Mittleman MA (2001) Increased particulate air pollution and the triggering of myocardial infarction. Circulation 103:2810-2815

Polichetti G, Cocco S, Spinali A et al (2009) Effects of particulate matter (PM 10, PM2.5, PM1.0) on the cardiovascular system. Toxicology 261:1-8

Pope CA III, Burnett RT, Thun MJ et al (2002) Lung cancer, cardiopulmonary mortality and long-term exposure to fine particulate air pollution. J Am Med Assoc 287:1132-1141

Regulation of the Minister of the Environment concerning the levels of certain substances in the air of 24 August 2012 (published in Dz.U. 2012, Item 1031)

Ribeiro CM, Pinho P, Llop E et al (2014) Associations between outdoor air quality and birth weight: a geostatistical sequential simulation approach in Coastal Alentejo, Portugal. Stoch Environ Res Risk Assess 28(3):527-540. doi:10.1007/s00477-0130770-6

Samek L (2009) Chemical characterization of selected metals by $\mathrm{X}$-ray fluorescence method in particulate matter collected in the area of Krakow, Poland. Microchem J 92(2):140-144

Samet JM, Dominici F, Curriero FC et al (2000) Fine particulate air pollution and mortality in 20 US cities 1987-1994. J Med 343:1742-1749

Satsangi PG, Yadaw S, Pipal AS, Kumbhar N (2014) Characteristics of trace metals in fine (PM2.5) and inhalable (PM10) particles and its health risk assessment along with in silico approach in indoor environment of India. Atmos Environ 92:384-393

Shao M, Tang X, Zhang Y et al (2006) City clusters in China: air and surface water pollution. Front Ecol Environ 4(7):353-361

Styszko K, Szramowiat K, Kistler M et al (2015) Mercury in atmospheric aerosols: a preliminary case study for the city of Krakow, Poland. C R Chim 18:1183-1191

Taiwo AM, Awomeso JA, Taiwo OT et al (2016) Assessment of health risks associated with road dusts in major traffic hotspots in Abeokuta metropolis, Ogun state, southwestern Nigeria. Stoch Environ Res Risk Assess. doi:10.1007/s00477-016-1302-y

Tan J, Zhang Y, Ma W et al (2016) Evaluation and potential improvements of WRF/CMAQ in simulating multi-levels air pollution in megacity Shanghai, China. Stoch Environ Res Risk Assess. doi:10.1007/s00477-016-1342-3

Taner S, Pekey B, Pekey H (2013) Fine particulate matter in the indoor air of barbeque restaurants: elemental compositions, sources and health risks. Sci Total Environ 454-455:79-87

Trojanowska M, Świetlik R (2012) Inhalacyjne narażenie środowiskowe mieszkańców miast Polski na metale ciężkie kadm i nikiel oraz arsen. Med Srod 15(2):33-41

Trojanowska M, Świetlik R (2013) Ocena ryzyka nowotworowego związanego $\mathrm{z}$ narażeniem inhalacyjnym na benzo(a)piren $\mathrm{W}$ wybranych miastach Polski. Med Srod 16(2):14-22
US EPA (2016) Integrated Risk Information System (IRIS). Glossary. http://www.epa.gov/iris/gloss8.htm Accessed 24 May 2016

US EPA (2007) Concepts, methods and data sources for cumulative health risk assessment of multiple chemicals, exposures and effects: a resource document, EPA/600/R-06/013F. National Center for Environmental Assessment, Office of Research and Development, Cincinnati

US EPA (2013) User's guide/technical background document for US EPA Region 9's RSL tables. US Environmental Protection Agency, Washington

Vienneau D, Perez L, Schindler C et al (2015) Years of life lost and morbidity cases attributable to transportation noise and air pollution: a comparative health risk assessment for Switzerland in 2010. Int J Hyg Environ Health 218:514-521

Villeneuve PJ, Chen L, Rowe BH, Coates F (2007) Outdoor air pollution and emergency department visits for asthma among children and adults: a case-crossover study in northern Alberta, Canada. Environ Health 6:40. doi:10.1186/1476-069X-6-40

Vineis P, Forastiere F, Hoek G, Lipsett M (2004) Outdoor air pollution and lung cancer: recent epidemiologic evidence. Int $\mathbf{J}$ Cancer 111(5):647-652

Wang B, Chen Z (2015) A model-based fuzzy set-OWA approach for integrated air pollution risk assessment. Stoch Environ Res Risk Assess 29(5):1413-1426. doi:10.1007/s00477-014-0994-0

Wang M, Beelen R, Stafoggia M et al (2014) Long-term exposure to elemental constituents of particulate matter and cardiovascular mortality in 19 European cohorts: results from the ESCAPE and TRANSPHORM projects. Environ Int 66:97-106

WHO (2016) WHO ambient air pollution database, May 2016

Wilczyńska-Michalik W, Michalik M (2015) Skład i pochodzenie cząstek pyłów w powietrzu atmosferycznym w Krakowie. Aura 3:12-16. doi:10.14199/2.2015.3.3

Wilczyńska-Michalik W, Pietras B, Samek L et al (2015) Submikronowe pyły w powietrzu atmosferycznym w Krakowie. Aura 8:4-7. doi:10.15199/2.2015.8.1

Wilson S, Burwell-Naney K, Jiang C et al (2015) Assessment of sociodemographic and geographic disparities in cancer risk from air toxics in South Carolina. Environ Res 140:562-568

WIOŚ (2016) Wojewódzki Inspektorat Ochrony Środowiska w Krakowie. http://monitoring.krakow.pios.gov.pl/

Wiwanitkit V (2008) PM10 in the atmosphere and incidence of respiratory illness in Chiangmai during the smoggy pollution. Stoch Environ Res Risk Assess 22:437-440. doi:10.1007/ s00477-007-0149-7

Worobiec A, Samek L, Krata A et al (2010) Transport and deposition of airborne pollutants in exhibition areas located in historical buildings-study in Wawel Castle Museum in Cracow, Poland. J Cult Herit 11:354-359

Yang Y, Fang W, Xue M et al (2016) TSP, PM10 and health risk assessment for heavy metals $(\mathrm{Cr}, \mathrm{Ni}, \mathrm{Cu}, \mathrm{Zn}, \mathrm{Cd}, \mathrm{Pb})$ in the ambience of the production line for waste cathode ray tube recycling. J Mater Cycles Waste Manag 18:296-302. doi:10. 1007/s10163-014-0331-1

Yu B, Huang C, Liu Z et al (2011) A chaotic analysis on air pollution index change over past 10 years in Lanzhou, northwest China. Stoch Environ Res Risk Assess 25(5):643-653. doi:10.1007/ s00477-011-0471-y

Zhou M, He G, Liu Y et al (2015) The associations between ambient air pollution and adult respiratory mortality in 32 major Chinese cities, 2006-2010. Environ Res 137:278-286 